\title{
Theca cells and the regulation of ovarian androgen production
}

\author{
Phil G. Knight* and Claire Glister \\ School of Biological Sciences, Hopkins Building, University of Reading, Reading, RG6 6UB, UK
}

\begin{abstract}
Summary
Theca cells are essential for female reproduction being the source of androgens that are precursors for follicular oestrogen synthesis and also signal through androgen receptors (AR) in the ovary and elsewhere. Theca cells arise from mesenchymal cells around the secondary follicle stage. Their recruitment, proliferation and cytodifferentiation are influenced, directly or indirectly, by paracrine signals from granulosa cells and oocyte although uncertainty remains over which are the critically important signals at particular stages. In a reciprocal manner, theca cells secrete factors that influence granulosa cell proliferation and differentiation at different follicle stages. Differentiated theca interna cells acquire responsiveness to luteinizing hormone ( $\mathrm{LH})$ and other endocrine signals and express components of the steroidogenic machinery required for androgen biosynthesis. They also express insulin-like peptide 3 (INSL3) and its receptor $(R X F P 2)$, levels of which increase during bovine antral follicle development. INSL3 signaling may play a role in promoting androgen biosynthesis since knockdown of either INSL3 or its receptor (RXFP2) in bovine theca cells inhibits androgen biosynthesis while exogenous INSL3 can raise androgen secretion. Bone morphogenetic proteins (BMPs) of thecal or granulosal origin suppress thecal production of both INSL3 and androgen. Inhibin, produced in greatest amounts by granulosa cells of preovulatory follicles, reverses these BMP actions. Thus, BMP-induced inhibition of thecal androgen production may be mediated by reduced INSL3-RXFP2 signaling. Activins also inhibit androgen production in an inhibin-reversible manner and recent evidence in sheep indicates that theca cells synthesize and secrete activin, implying an autocrine role in suppressing androgen biosynthesis in smaller follicles, akin to that envisaged for BMPs.
\end{abstract}

\section{Introduction}

Ovarian androgens play an essential role in female reproductive physiology being obligatory substrates for ovarian oestrogen synthesis as well as having direct androgen receptor (AR)- 
mediated actions in the ovary and elsewhere. Indeed female mice lacking functional AR show defective follicle development and premature ovarian failure (Shiina et al. 2006). Ovary- and adrenal-derived androgens can also be aromatized to oestrogens by various peripheral tissues including brain, bone and adipose tissue (Simpson 2003) reflecting additional 'non-reproductive' roles.

Evidence that the mammalian ovary synthesises and secretes androgens first emerged in the 1930s (Deanesly 1938). It was subsequently revealed that theca interna cells of developing antral follicles are their principle source and that the capacity of ovarian follicles to synthesise oestrogens depended on the cooperation of theca interna and granulosa cells in accordance with the two-gonadotrophin, two-cell theory (Ryan \& Petro 1966, Fortune \& Armstrong 1977). This theory proposed that luteinizing hormone $(\mathrm{LH})$ acts on theca interna cells to promote biosynthesis of androgens (androstenedione, testosterone), which then diffuse to neighbouring granulosa cells where the aromatase enzyme complex converts them to oestrogens (oestrone, oestradiol), under the influence of follicle stimulating hormone (FSH). Whilst the two-cell, twogonadotrophin theory has stood the test of time remarkably well, it is increasingly evident that additional endocrine signals and a multitude of locally-produced signals also contribute to the regulation of thecal androgen production and granulosal oestrogen production at successive stages of follicle development.

The physiological importance of theca-derived androgens cannot be overstated since several key events in the female reproductive process (follicle maturation, preparation of reproductive tract, generation of preovulatory LH surge, ovulation, oestrus behaviour, libido) are reliant upon their timely production. Unfortunately, disorders that affect thecal androgen biosynthesis, such as polycystic ovarian syndrome (PCOS) in humans, are commonplace and are associated with impaired fertility and other co-morbidities (Baptiste et al. 2010). Given the above, it is perhaps surprising that theca cells have not commanded more attention by ovarian biologists over recent decades. Recent PubMed searches yielded cumulative hits totalling 63,492, 13,918 and 3,658 for the terms "oocyte", "granulosa cell" and "theca cell" respectively, supporting this perception.

The aim of this review is to provide an update of the literature on ovarian theca cells and androgen production with an emphasis on studies involving domestic ruminants. We will also discuss in more detail recent findings from our own laboratory on the actions and interaction of bone morphogenetic proteins (BMPs) and insulin-like peptide 3 (INSL3) on androgen production by bovine theca cells. The reader will find much additional information on theca cells in excellent review articles (Erickson et al. 1985, Magoffin 2005, Tajima et al. 2007, Young \& McNeilly 2010).

\section{Formation of the theca layer}

Recruitment of theca cells from ovarian stroma

It is generally accepted that theca cells are derived from mesenchymal progenitor cells within the cortical stroma. There is some evidence in the mouse that a definitive population(s) of thecal progenitor stem cells exists (Honda et al. 2007) although comparable studies are currently lacking in other species including ruminants. Under the influence of presumptive signals emitted by activated preantral follicles (i.e. primary and secondary stage), stromal progenitor cells congregate around the follicular basal lamina and align to form first one, and subsequently multiple layers of elongated cells surrounding the follicle (Erickson et al. 1985, Orisaka et al. 2006b, Itami et al. 2011). Thecal recruitment occurs independently of gonadotrophin action as the stromal progenitor cells do not express LH receptors and the theca layer still forms in 
FSH receptor-null mice (Kumar et al. 1997, Abel et al. 2000). Rather, evidence suggests that soluble factor(s) secreted by the oocyte and/or granulosa cells of activated follicles drive thecal recruitment (Magoffin 2002, Magoffin 2005, Orisaka et al. 2006b, Itami et al. 2011). Whilst the identity of the key factor(s) involved is still unknown, granulosa-derived kit ligand (KITLG) and hedgehog proteins, and oocyte-derived GDF9 are prime candidates. Theca layers fail to develop in the arrested follicles of GDF9-null mice (Elvin et al. 1999). GDF9 may act either directly on surrounding stromal (pre-theca) cells to upegulate KIT expression or indirectly by modulation of KITLG and IGF1 production by granulosa cells that, in turn, binds to their signaling receptors (KIT, IGFR) on pre-theca cells (Nilsson \& Skinner 2002). Like GDF9, oocyte-derived BMP15 has also been shown to upregulate KITLG expression by granulosa cells (Otsuka \& Shimasaki 2002).

From the primary follicle stage in mice, granulosa cells begin to express hedgehog proteins (Ihh, Dhh) that induce target gene expression (Ptch1, Gli1) in surrounding mesenchymal stromal cells (i.e. pre-theca cells). This expression pattern persists in the theca layer until the preovulatory stage, perhaps implying a role in both theca cell recruitment and differentiation (Wijgerde et al. 2005). Cultured bovine theca cells from antral follicles also respond to hedgehog protein with upregulation of Gli1 expression, increased proliferation and androgen production (Spicer et al. 2009). Other candidate theca recruitment factors include VEGFA (Yang \& Fortune 2006, Yang \& Fortune 2007) from granulosa cells and BMP15 and BMP6 from the oocyte. In addition, evidence suggests that established theca cells also secrete paracrine factors that indirectly influence surrounding stromal cells to 'amplify' recruitment including transforming growth factor $\alpha$ (TGFA), basic fibroblast growth factor (bFGF/FGF2), keratinocyte growth factor (KGF/ FGF7), hepatocyte growth factor (HGF), IGFs and androgens. Both KGF and HGF have been shown to increase granulosal KITLG expression that, in turn, upregulates thecal FGF7and HGF expression (Parrott \& Skinner 1998) as well as stromal KIT expression and cell proliferation (Parrott \& Skinner 2000). Theca-derived androgens may also have an amplifying role since androgen can upregulate KITLG expression by mouse granulosa cells (Joyce et al. 1999) and promote the primary to secondary follicle transition in bovine ovarian cortical strips (Yang \& Fortune 2006, Yang \& Fortune 2007).

\section{Proliferation and differentiation of theca cells}

After congregating around the basal lamina, theca cells proliferate and differentiate into an inner theca interna and outer theca externa. Whilst the key signals responsible are largely unknown, proliferation and cytodifferentiation are presumably influenced by gradients of paracrine signaling molecules from the centrally located granulosa/oocyte compartment (i.e. KITLG, GDF9, BMP15, EGF, hedgehog proteins) in conjunction with endocrine signals (i.e. LH, insulin, IGFs) diffusing from new capillary vessels forming close to the basal lamina. Once established, theca cells may also secrete autocrine/paracrine factors that promote further proliferation and differentiation, including IGFs (Barbieri et al. 1986, Magoffin \& Weitsman 1994, Spicer et al. 2004), bFGF (Nilsson et al. 2001) and androgens (Yang \& Fortune 2006, Yang \& Fortune 2007). Evidence in the mouse suggests that a radial signaling gradient of hedgehog proteins emitted by granulosa cells is involved in the differentiation of the more distantly located theca cells into theca externa cells that show a smooth muscle-like phenotype (Ren et al. 2009). In contrast, theca interna cells acquire $L H$ receptors and begin to express components of the steroidogenic pathway (NR5A1, STAR, CYP11A1, HSD3B1, CYP17A1). Morphologically, theca interna cells display hallmark features of steroidogenically-active cells, including abundant smooth endoplasmic reticulum, numerous mitochondria with tubular cristae and lipid vesicles that store cholesterol esters as precursor for the synthesis of steroid hormones. As mentioned 
above, theca externa cells lack these features and have a morphology more akin to smooth muscle cells, indicative of a more structural or mechanical support role in the follicular unit. There is some evidence that theca externa cells exhibit contractile behaviour around the time of ovulation that may contribute to extrusion of the cumulus-oocyte and wound closure around the margin of the corpus haemorrhagicum (Hunter 2003).

As secondary follicles progress towards the antral stage they acquire their own vascular supply in the form of a sheath of capillaries coursing throughout the theca layer; these capillaries are excluded by the basal lamina from the avascular granulosal compartment, until follicle luteinisation (or atresia). A well-developed thecal capillary bed is essential for bidirectional transfer of substances to (e.g. gonadotrophins, nutrients) and from (e.g. steroids, metabolites) the follicular unit. VEGF and other pro-angiogenic factors expressed predominantly by granulosa cells play a prominent role in vascularization of the theca interna (Fraser 2006, Fraser \& Duncan 2009, Robinson et al. 2009). Inhibition of VEGFA signaling leads to reduced proliferation of endothelial and theca cells, compromises follicle development and blocks ovulation (Fraser 2006). Treatment of bovine cortical strips with VEGFA promotes primary to secondary follicle transition (Yang \& Fortune 2006, Yang \& Fortune 2007). Recent evidence in cattle indicates that theca-derived BMP4 and BMP7 may contribute to thecal vascularization by upregulating VEGFA expression in granulosa cells (Shimizu et al. 2012).

\section{A brief life history of theca cells: from recruitment to luteal regression}

It is clear that the capacity of stromal progenitor cells to differentiate into theca cells persists throughout the reproductive lifespan of a female (i.e. until the primordial follicle reserve is depleted). Whilst a theoretical possibility, we are not aware of any evidence that failure of thecal recruitment ever becomes a limiting factor in the supply of growing preantral follicles in females approaching the end of their reproductive lifespan. The subsequent fate of established theca cells (and their progeny) largely corresponds to the developmental trajectory of the individual follicle, $>99 \%$ of which are lost through atresia during the 4-6 months it takes for a primary follicle to reach the preovulatory stage in sheep, cattle and humans (Lussier et al. 1994). Inadequate development and/or early regression of the thecal vasculature is reportedly a common feature of atretic follicles (Fraser 2006). A detailed discussion of follicle atresia in the bovine and how this relates to changes in theca cells, granulosa cells and oocyte may be found elsewhere (Rodgers \& Irving-Rodgers 2010). Comprehensive reviews focussing on follicle vascularization include Robinson et al. (2009) and Fraser \& Duncan (2009).

Once follicles have acquired a well-developed capillary network it seems reasonable to assume that their theca interna cells are exposed to pituitary $\mathrm{LH}$ pulses and other endocrine signals, regardless of the stage of follicle development. However, androgen production remains at relatively low levels during preantral and early antral follicle stages, only increasing markedly during the mid- to late-antral stage. This implies the involvement of other, locally produced signals that suppress androgen production at earlier follicle stages whilst augmenting $\mathrm{LH}$ dependent androgen production at later stages. Intraovarian factors implicated in the regulation of androgen production are discussed in more detail in the final section of this review.

For selected bovine antral follicles that achieve dominance around the time of luteal regression, exposure to the ovulation-inducing $\mathrm{LH}$ surge initiates luteinisation of both theca and granulosa cells, characterised by an abrupt loss of thecal CYP17A1 expression and androgensynthesizing capacity, and granulosal CYP19A1 expression and oestrogen-synthesizing capacity (Voss \& Fortune 1993). Instead, the proximal components of the steroidogenic pathways of 
both cell types are upregulated (i.e. STAR, CYP11A1, HSD3B1) and predominantly used for the synthesis of progesterone as theca cells transform into 'small' luteal cells and granulosa cells become 'large' luteal cells of the newly formed corpus luteum. Both 'small' and 'large' luteal cells actively secrete progesterone until corpus luteum regression (Berisha \& Schams 2005, Miyamoto et al. 2010).

\section{Paracrine effects of theca interna cells on granulosa cells and oocyte}

In addition to supplying androgens to granulosa cells as substrates for aromatization to oestrogens, theca cells express an array of paracrine signaling molecules shown to influence the proliferation and differentiated function of granulosa cells at different stages of follicle development (Orisaka et al. 2006a). Prominent amongst these are androgens themselves that have been shown to act via AR to promote follicle development (Vendola et al. 1999, Shiina et al. 2006, Yang \& Fortune 2006), upregulate FSHR and CYP19A1 expression (Luo \& Wiltbank 2006) and FSH-induced oestrogen production (Hillier \& De Zwart 1981, Harlow et al. 1986, Weil et al. 1999). Thus, thecal androgens play a vital role in promoting granulosal CYP19A1 expression/aromatase activity as well as providing substrate for the enzyme.

Many non-steroidal factors secreted by theca cells have likewise been shown to modify granulosa cell proliferation and/or function in ruminants and other species (Fig. 1). For example, in vitro studies on bovine/ovine follicles show that theca-derived KGF (FGF7) and HGF promote granulosa cell proliferation (Parrott et al. 1994, Parrott \& Skinner 1998), TGFB1

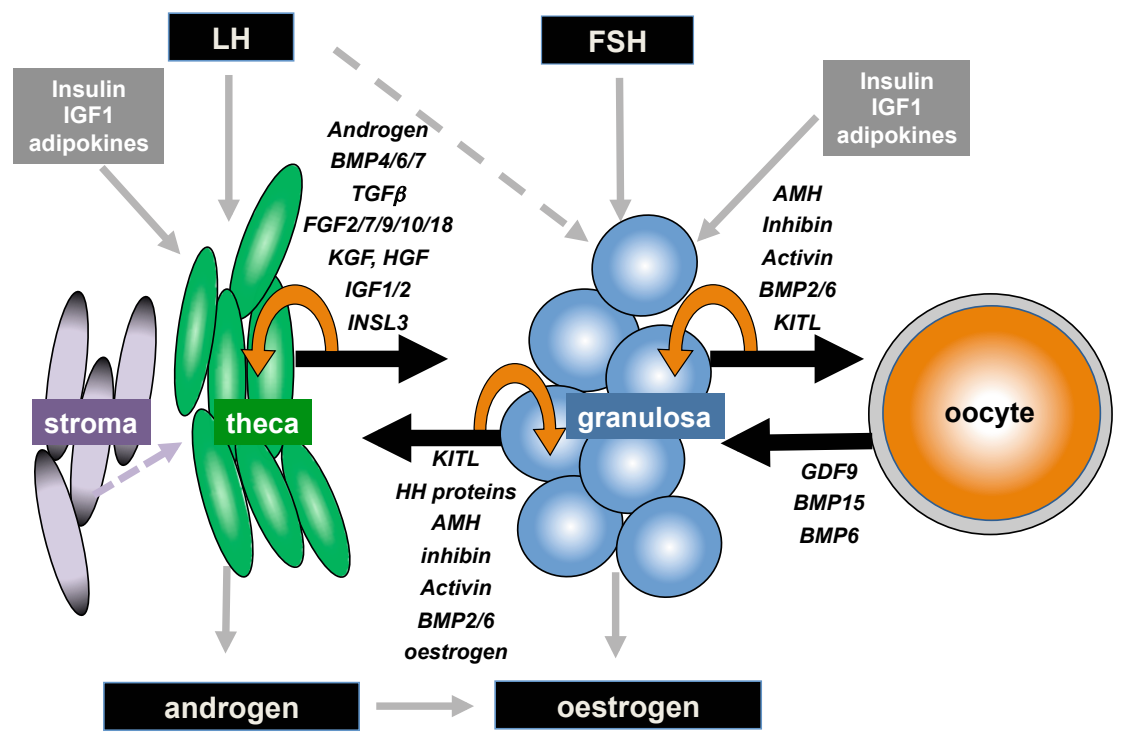

Fig. 1. Theca cells are recruited from cortical stromal cells and proliferate and differentiate under the influence of paracrine factors secreted by the granulosa cells and/or oocyte of activated follicles. Differentiated theca interna cells are responsive to $\mathrm{LH}$ and other endocrine and intra-ovarian factors. In turn, they secrete factors (steroids and proteins) that exert autocrine/paracrine effects on theca cells and paracrine effects on granulosa cells. They also deliver androgens to granulosa cells as substrate for oestrogen synthesis. Abbreviations: AMH, anti-mullerian hormone; BMP, bone morphogenetic protein; IGF, inslulin-like growth factor; INSL3, insulin-like peptide 3; GDF, growth and differentiation factor; HGF, hepatocyte growth factor; $\mathrm{HH}$ proteins, hedgehog proteins; KITL, kit ligand (stem cell factor); TGF, transforming growth factor. Black arrows indicate paracrine effects while orange arrows indicate autocrine effects. Grey arrows and grey dashed arrows indicate endocrine effects. 
down-regulates FSH-induced CYP19A1 expression and oestradiol secretion (Ouellette et al. 2005, Zheng et al. 2008), IGF1 enhances cell proliferation and oestradiol secretion (Gutierrez et al. 1997, Glister et al. 2001, Monget et al. 2002), BMP4, BMP6 and BMP7 enhance basal and IGF-induced oestradiol secretion (Monget et al. 2002, Glister et al. 2004, Campbell et al. 2006). In contrast, FGF10 inhibits oestradiol secretion (Buratini et al. 2007) while FGF18 inhibits FSHR expression and steroidogenesis and promotes cell death (Portela et al. 2010). Since thecal expression of FGF18 mRNA and FGF18 protein in follicular fluid were higher in subordinate than in dominant follicles, it was suggested that theca-derived FGF18 might be an important atretogenic factor in bovine follicles (Portela et al. 2010). It should be cautioned that expression of many of the above proteins is not exclusive to theca cells and so the observed effects of purified/recombinant proteins on granulosa cells is not necessarily indicative of theca-granulosa interaction.

\section{Thecal steroidogenesis and factors modulating androgen secretion}

Endocrine factors

In response to pulses of $\mathrm{GnRH}$ from the hypothalamus, pituitary gonadotrophs secrete LH pulses that, in turn, promote transient increases in ovarian output of androgens and oestrogens (Baird \& McNeilly 1981, Campbell et al. 1990). The frequency and amplitude of LH pulses are modulated by both extrinsic (e.g. photoperiod, socio-sexual cues) and intrinsic (e.g steroid feedback) influences (Martin 1984) and vary according to the stage of the reproductive cycle. LH plays a major role in promoting androgen production by theca interna cells, particularly those of antral follicles with a well-developed vascular system. It does so by upregulating the expression of several key genes involved in the steroidogenic pathway that converts cholesterol into androgen, including STAR, CYP11A1 and CYP17A1. As would be anticipated from this, treatment of cows with a GnRH antagonist (acyline) to block pulsatile LH secretion inhibited thecal STAR and CYP17A1 mRNA levels and reduced androgen production (Luo et al. 2011).

Thecal androgen production is also enhanced by insulin, as revealed by in vitro studies on theca cells from several species including cattle, sheep and human (Spicer \& Echternkamp 1995, Campbell et al. 1998, Franks et al. 1999). This has given rise to the theory that raised insulin levels in women with insulin resistance could be a contributory factor in the aetiology of polycystic ovarian syndrome, a condition usually associated with ovarian androgen excess and arrested antral follicle development (Baptiste et al. 2010). Like insulin, IGF1 can also stimulate thecal androgen production (Velazquez et al. 2008) while the adipokines leptin (Spicer 2001) and adiponectin (Lagaly et al. 2008) have been shown to inhibit thecal androgen production by cultured bovine theca cells.

\section{Intra-ovarian factors}

In concert with LH and other endocrine factors, numerous locally-produced growth factors have been implicated as intra-ovarian regulators of thecal androgen production. These include KITLG (Parrott \& Skinner 1997), IGFs (Campbell et al. 1998, Spicer et al. 2004), bFGF/FGF2 (Hurwitz et al. 1990, Scaramuzzi \& Downing 1995), FGF9 (Schreiber et al. 2012), EGF (Scaramuzzi \& Downing 1995, Campbell et al. 1998), TGFA (Roberts \& Skinner 1991, Campbell et al. 1994) TNFA (Spicer 1998), interleukins (Hurwitz et al. 1991) and multiple TGF $\beta$ superfamily members (reviews: Woodruff \& Mather 1995, Shimasaki et al. 2004, Knight \& Glister 2006) (Fig. 2). 


\begin{tabular}{|c|}
\hline Inhibitory factors \\
\hline Activin $\mathrm{A} / \mathrm{Bg}^{\mathrm{g}(\mathrm{t})}$ \\
\hline $\mathrm{BMP}^{\mathrm{g}}, 4^{\mathrm{t}}, 6^{\mathrm{got}}, 7^{\mathrm{t}}$ \\
\hline AMHg \\
\hline TGF $\beta^{g t}$ \\
\hline FGF2 ${ }^{g t}$ \\
\hline FGF9t \\
\hline EGF $^{g t}$ \\
\hline TGF $\alpha^{g t}$ \\
\hline $\mathrm{TNF} \alpha^{\mathrm{m}(\mathrm{go})}$ \\
\hline $\mathrm{IL} 1 \alpha / \beta^{\mathrm{cm}}$ \\
\hline Leptine \\
\hline Adiponectin \\
\hline GDF9० (in bovine, human) \\
\hline Oestradiolg (in rodent) \\
\hline
\end{tabular}

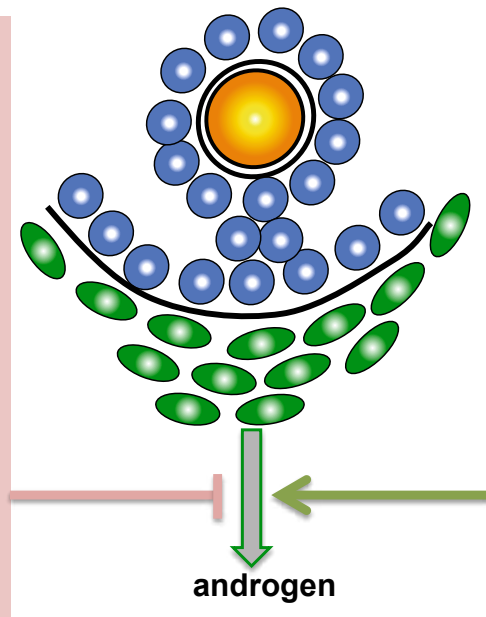

Stimulatory factors
LH $^{\mathrm{e}}$
Insulin
IGFct
KITLg
KGF
HGF $^{\mathrm{t}}$
Hedgehog proteins
INSL3
Inhibing
Follistating
Gremlingt
GDF9॰ (in rodent)
Oestradiolg (in bovine/human)

Fig. 2. Systemic and intra-ovarian factors shown to modulate thecal androgen production in vitro. So far, only a minority of these factors (highlighted in bold) has been shown to modulate ovarian androgen production in vivo (evidenced by experiments involving direct administration, immunoneutralization, spontaneous mutations or targeted deletions of ligand/receptor genes). More in vivo studies are required to strengthen the physiological relevance of in vitro observations relating to local autocrine/paracrine interactions. However, such experiments are challenging, not least due to multiple sites of action and complex hypothalamic-pituitary-ovarian feedback interactions operating in vivo. Superscript letters indicate the main source(s) of each factor: e, endocrine; g, granulosa; m, macrophage; o, oocyte; $t$, theca. For other abbreviations see Fig. 1 legend.

Theca cells express a full complement of receptors and intracellular signal transduction components for TGF $\beta$ superfamily members and are responsive to multiple ligands including TGF $\beta$, activins, BMP2, BMP4, BMP6, BMP7 and $\mathrm{AMH}$, all of which are expressed at the intrafollicular level and have been shown to attenuate basal and/or LH-induced androgen production in several species including rat, human, cattle and sheep (Brankin et al. 2005, Glister et al. 2005, Campbell et al. 2006, Glister et al. 2010, Glister et al. 2011, Campbell et al. 2012, Young et al. 2012, Young \& McNeilly 2012). The suppressive effect of activin-A is antagonised by follistatin and inhibin (Wrathall \& Knight 1995, Young et al. 2012, Young \& McNeilly 2012). Activin-B also suppresses androgen production by sheep theca cells to a similar extent as activin-A, and the effects of both are effectively reversed by inhibin-A (Young et al. 2012).

In addition to blocking activin signaling, inhibin-A was shown to antagonise the suppressive effects of BMP2, 4, 6 and 7 on bovine theca cells (Glister et al. 2010). This was accompanied by a reversal of a marked BMP-induced decline in expression of CYP17A1 and, to a lesser extent, LHCGR, STAR, CYP11A1 and HSD3B1 expression. In sheep theca cells, the inhibitory effect of activin-A on androgen production was associated with a decline in STAR and HSD3B1 expression while CYP17A1 expression was unaffected (Young \& McNeilly 2012). However, co-treatment with inhibin-A to reverse the activin-induced suppression of thecal androgen production, led to an increase in expression of CYP17A1 and HSD3B1. Furthermore, treatment with inhibin alone raised CYP17A1 expression and androgen production indicating that sheep theca cells produce an endogenous ligand whose action is opposed by inhibin. The finding that follistatin treatment alone also raised androgen secretion indicates that activin is the 
endogenous ligand produced by sheep theca cells (Young \& McNeilly 2012). Indeed, the same group reported expression of INHBA and INHBB mRNAs in the theca layer of sheep antral follicles (Young et al. 2012). In contrast, whilst studies in the authors' laboratory have also documented expression of INHBA and INHBB mRNAs in bovine theca layers (Glister et al. 2010), we found no stimulatory effect of follistatin treatment on androgen secretion by isolated theca interna cells (C Glister \& P G Knight 2013, unpublished observations). Therefore, we interpret the ability of inhibin alone to raise androgen production as being due to antagonism of endogenous BMPs, that are also expressed by theca cells (Glister et al. 2010).

It was recently reported that $\mathrm{AMH}$ also exerts a suppressive effect on $\mathrm{LH}$-induced androgen production by cultured sheep theca cells (Campbell et al. 2012). Moreover, AMH immunoreactivity in granulosa cells declined during follicle development and was inversely associated with aromatase immunoreactivity. The study also found that active immunization of sheep against $\mathrm{AMH}$ was associated with raised intrafollicular androgen concentrations in small antral follicles, supporting a physiological role for granulosa-derived $\mathrm{AMH}$ as an additional paracrine factor that can suppress thecal androgen production.

Taken together, the above evidence indicates that multiple intra-follicular TGF $\beta$ family members including activins, BMPs and $\mathrm{AMH}$ negatively regulate basal and $\mathrm{LH}$-induced androgen production. In contrast, inhibins, follistatin and likely several BMP binding proteins (e.g. chordin, gremlin, noggin) secreted by granulosa cells (Glister et al. 2011) oppose these signals and upregulate androgen production. Granulosal production of inhibin and follistatin, as well as thecal expression of the inhibin co-receptor, betaglycan (Glister et al. 2010), increases in growing preovulatory follicles and, by counteracting activin/BMP signaling on theca cells, this would serve to enhance the ability of theca cells to deliver sufficient androgen to granulosa cells for aromatization to oestrogen. It should be noted that recent evidence in sheep (Young et al. 2012) and cattle (Glister et al. 2010) indicates that theca cells also express mRNAs for inhibin/activin subunits. This raises the possibility that theca cells, as well as granulosa cells, secrete functional inhibin/activin proteins that contribute to the regulation of thecal androgen production and other intrafollicular events. Further work is needed to investigate this aspect of intrafollicular regulation.

In vitro studies on bovine (Roberts \& Skinner 1990, Wrathall \& Knight 1995) and human (Gilling-Smith et al. 1997) theca cells have shown that oestradiol itself, at physiological concentrations (i.e. similar to peak concentrations in antral fluid) can upregulate thecal androgen production. This indicates that an additional intra-follicular positive feedback loop operates to ensure an adequate supply of androgen for conversion to oestrogen in the late follicular phase. A recent study in rats also provided evidence that, in addition to inhibin, another FSH-dependent paracrine factor from granulosa cells (oestradiol?) was capable of upregulating thecal CYP17A1 expression (Hoang et al. 2013).

With regard to potential regulatory roles of oocyte-derive factors on thecal androgen production, GDF9 was found to enhance forskolin-stimulated androgen production by rat theca-interstitial cells (Solovyeva et al. 2000) while GDF9-induced upregulation of androgen secretion and CYP17A1 expression in rat preantral follicles was blocked by intra-oocyte injection of GDF9 antisense nucleotide (Orisaka et al. 2009). However, other studies showed that GDF9 inhibits forskolin-induced androgen production by human theca cells (Yamamoto et al. 2002) and both LH- and IGF1-induced androgen production by bovine theca cells (Spicer et al. 2008). Whether these discordant findings reflect species differences, or differences in experimental methodology is not known at this time. Nonetheless, the likelihood is that oocyte-derived factors do exert direct regulatory actions on surrounding theca cells, as well as on granulosa cells. 


\section{Evidence for interactions between BMP and insulin-like peptide 3 (INSL3) signaling in regulating theca androgen production}

As mentioned above studies in the authors' laboratory using bovine theca cells in primary culture showed that bone morphogenetic proteins (BMPs) are powerful suppressors of thecal androgen production and that granulosa-derived inhibin can antagonise this effect of BMPs and raise androgen production (Glister et al. 2005, Glister et al. 2010). Likewise, several BMP-binding proteins (gremlin, noggin) can reverse the inhibitory effect of BMPs (Fig. 3), and multiple BMP-binding proteins are expressed in the bovine ovary, particularly by granulosa cells (Glister et al. 2011). In a subsequent microarray study (Glister et al. 2013) we showed that BMP treatment down-regulates expression of several hundred genes in theca cells including multiple components of the steroidogenic pathway leading to androgen biosynthesis, most prominently CYP17A1 but also NR5A1, STAR, CYP11A1 and HSD3B1. Intriguingly, thecal expression of insulin-like peptide 3 (INSL3) was profoundly suppressed by BMP treatment and this prompted a series of experiments that revealed a hitherto unknown functional link between BMP and INSL3 pathways in the regulation of ovarian androgen production (Glister et al. 2013, Satchell et al. 2013). INSL3 was initially identified as a testicular product, but it has become evident that the ovary also synthesizes substantial amounts of INSL3 (review: Ivell \& Anand-Ivell 2011). In the bovine ovary, both INSL3 and its cognate receptor (RXFP2) are

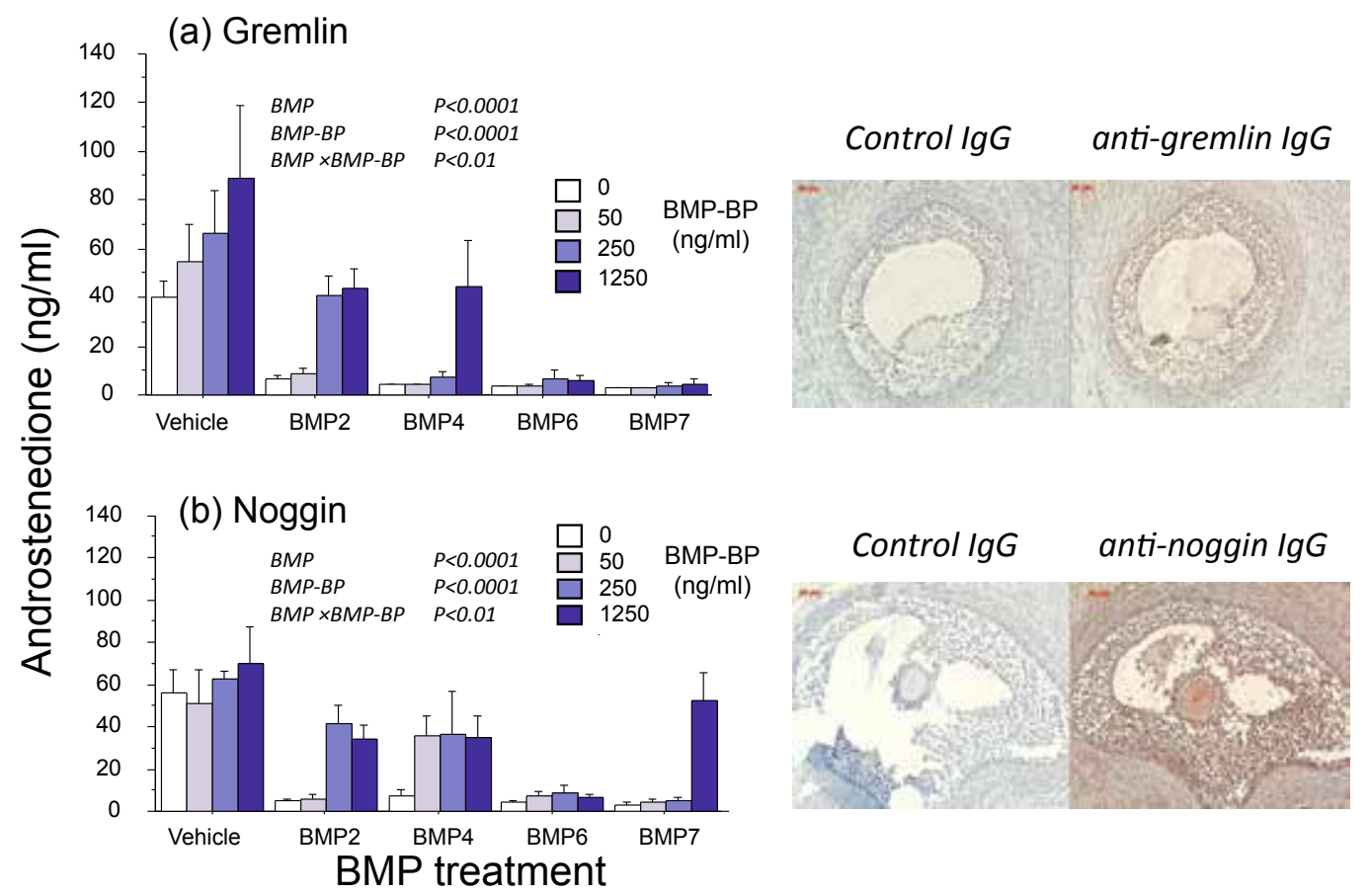

Fig. 3. The BMP-binding proteins gremlin and noggin are expressed in bovine antral follicles and can selectively antagonize BMP-induced suppression of androstenedione secretion by bovine theca cells in vitro. Note that gremlin also raises 'basal' androstenedione secretion in the absence of BMP treatment, suggesting neutralization of an endogenous ligand, likely BMP4. (C Glister, L Satchell \& P G Knight 2013, unpublished observations). 
predominantly expressed by theca cells and expression levels of both increase during antral follicle development (Satchell et al. 2013). In rat preantral follicles expression of RXFP2 was also detected in oocytes and INSL3 was shown to upregulate GDF9 expression, follicle growth and androgen production (Xue et al. 2014). Using cultured bovine theca cells, RNAi-mediated knockdown of either INSL3 or its receptor RXFP2 was shown to suppress androgen production (Fig. 4) whereas exogenous synthetic human INSL3 promoted a modest increase in androgen production (Glister et al. 2013). During the synchronized bovine oestrous cycle plasma INSL3 levels increase during the preovulatory period and then decline after the $\mathrm{LH}$ surge, paralleling the changes in plasma oestradiol (Satchell et al. 2013) (Fig. 5). This suggests that the peak in circulating INSL3 reflects the output of theca cells of the dominant ovulatory follicle and that the subsequent fall in INSL3 after the LH surge reflects diminished thecal output associated with follicle luteinisation. In support of this, in vitro culture of theca cells with a luteinizing concentration of LH promoted a marked decline in INSL3 mRNA expression and INSL3 secretion accompanied by an upregulation of STAR and CYP11A1 expression and progesterone secretion (Satchell et al. 2013).

\section{INSL3 knockdown}
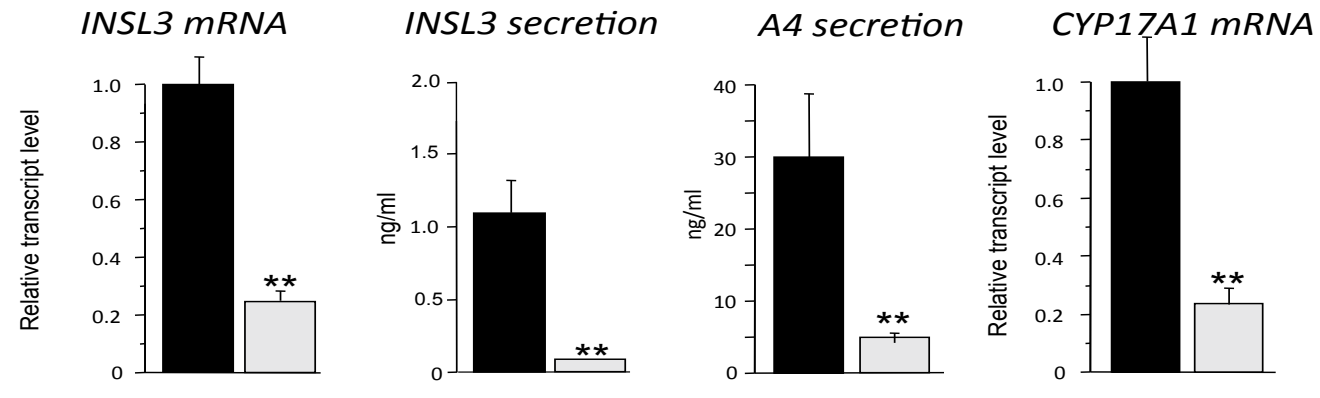

\section{RXFP2 knockdown}
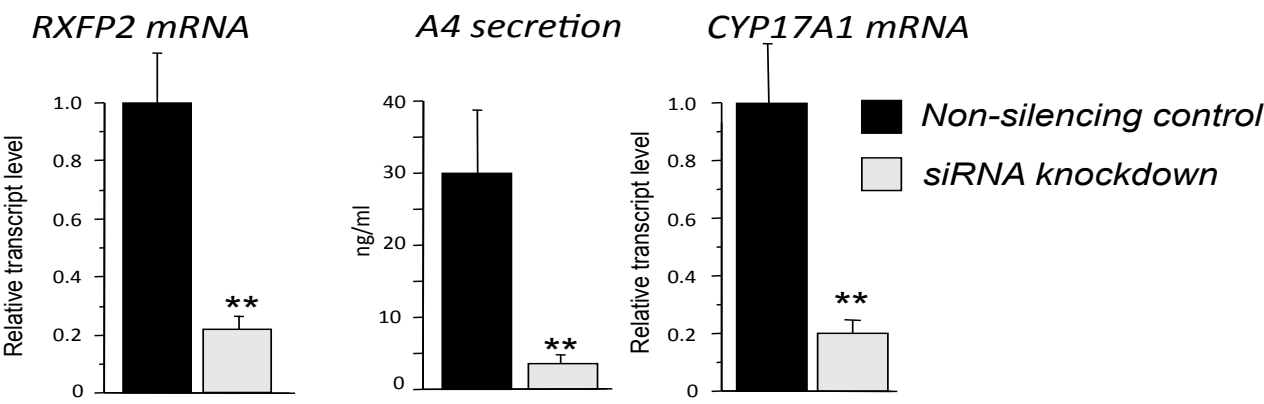

Fig. 4. RNAi knockdown of INSL3 or its receptor (RXFP2) in cultured bovine theca cells reduces CYP17A1 expression and androstenedione secretion indicating that INSL3 signaling is required for maintaining androgen synthesis. Values are means \pm SEM ( $n=4$ independent cultures). ${ }^{*} * P<0.01$ versus control. (redrawn from Glister et al 2013).

Collectively, these findings revealed the importance of another intraovarian growth factor, INSL3, for maintaining androgen production by ovarian theca cells and showed that the suppressive action of BMPs on androgen production is intimately linked to their inhibition of INSL3 signaling. On the basis of these findings we propose that a functional deficit in thecal BMP signaling promotes excess thecal INSL3-RXFP2 signaling and that this could be a contributory factor in ovarian androgen excess disorders such as PCOS. Indeed, circulating INSL3 levels are raised in women with PCOS (Gambineri et al. 2011, Anand-Ivell et al. 2013). Conversely, 

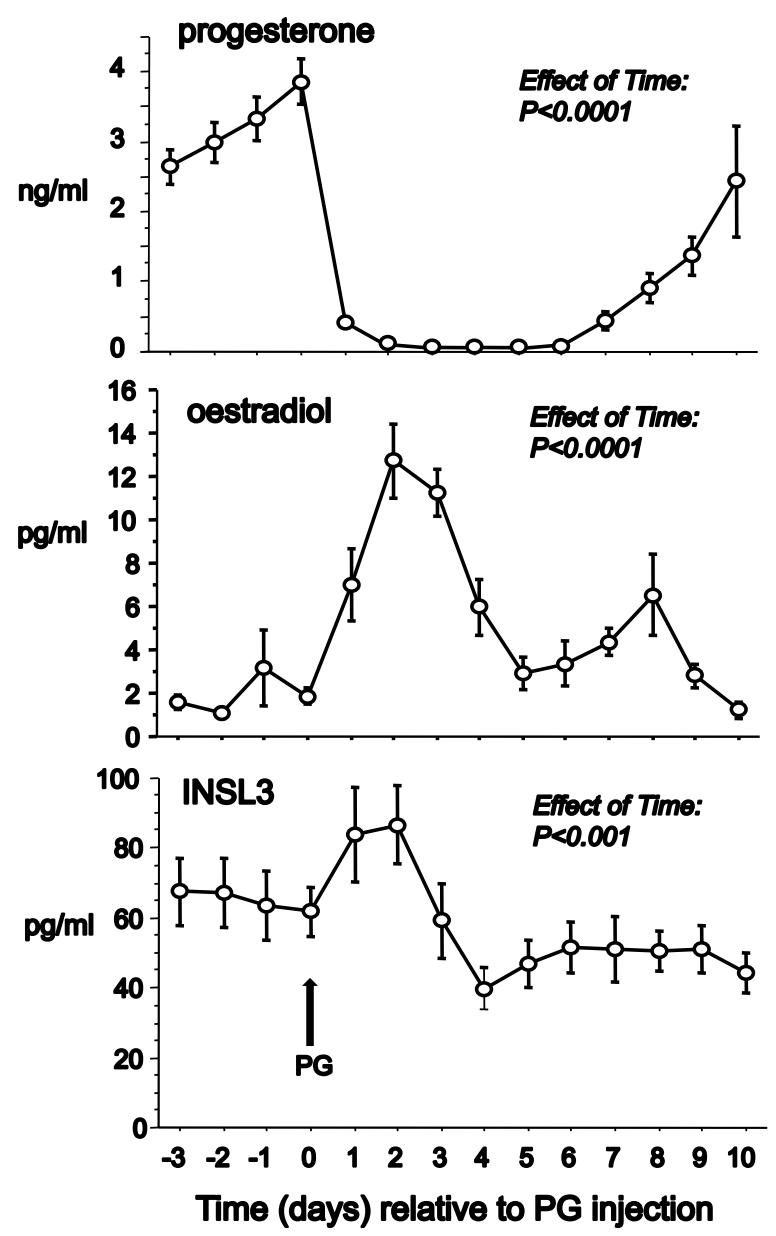

Fig. 5. Changes in mean $( \pm$ SEM) plasma concentrations of progesterone, oestradiol$17 \beta$ and INSL3 during PG-synchronized oestrous cycles in heifers. Samples are aligned to the time of PG administration (day 0) indicated by the arrow. Statistical analysis was performed by repeated measures ANOVA. (replotted from Satchell et al 2013).

a functional excess of thecal BMP signaling could contribute to androgen insufficiency by reducing INSL3-RXFP2 signaling. Both situations compromise normal follicle development and lead to subfertility or infertility in animals and human. Moreover, the extra-ovarian actions of androgens, either acting directly or after peripheral conversion to oestrogens, will be perturbed by over- or under-secretion of ovarian androgen.

\section{Conclusions}

In summary, theca interna cells have an indispensible role in the ovary, not only contributing to preantral and antral follicle development mediated by androgen receptor interaction, but also in the timely provision of androgen substrate required for granulosal oestrogen biosynthesis, particularly in the final preovulatory stage of follicle development. It has become apparent that theca cells are closely regulated by an array of intra-ovarian factors that operate in concert with $\mathrm{LH}$ and other endocrine signals to modulate follicular androgen biosynthesis. Intra-ovarian BMPs and the INSL3-RXFP2 system are recent additions to this list and, based on findings from the authors' laboratory, a schematic model depicting their proposed involvement is presented in Fig. 6. Dysregulation of ovarian androgen production is a likely consequence of perturbations 


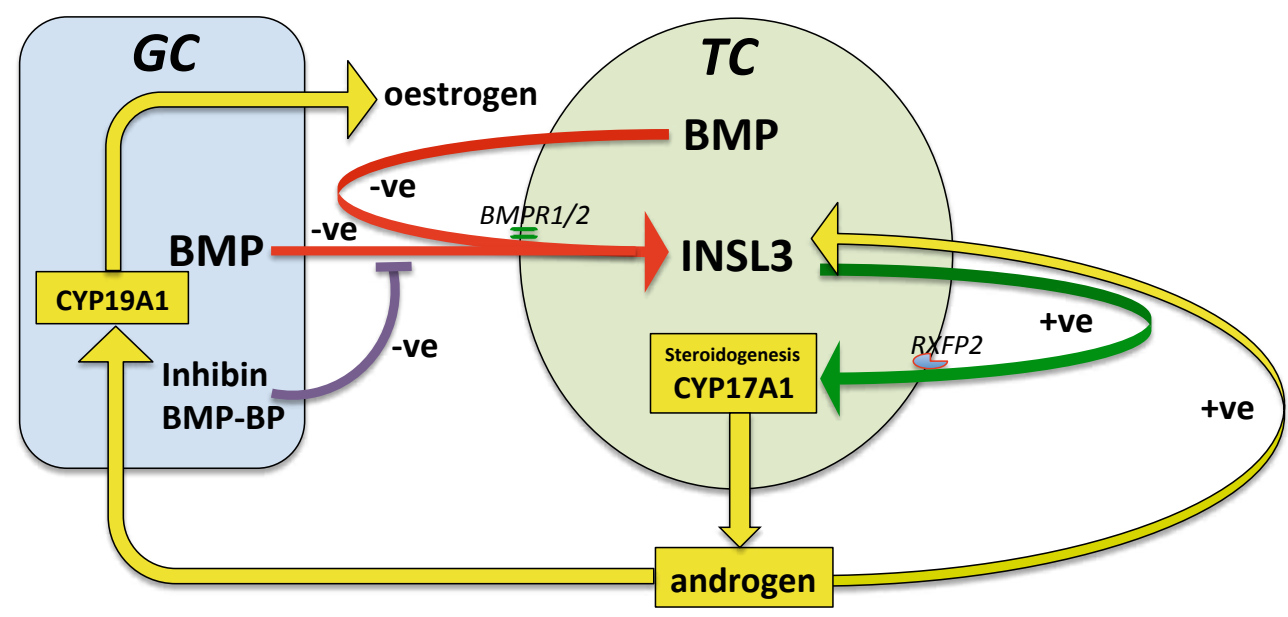

Fig. 6. Putative model of BMP-INSL3 pathway interaction in the regulation of thecal androgen production. According to the model (a) both INSL3 and its cognate receptor RXFP2 are primarily expressed by theca cells (TC); (b) expression of INSL3 and RXFP2 increase during antral follicle development and decline after the preovulatory LH surge; (c) INSL3-RXFP2 signalling is required to sustain TC androgen production since knockdown of either suppresses CYP17A1 expression and androgen production; (d) in a feed forward manner androgens positively regulate INSL3-RXFP2 signaling since pharmacological blockade of androgen synthesis reduces INSL3 and RXFP2 expression; (e) BMPs from granulosa cells (GC) and/or TC suppress INSL3 expression and this is accompanied by a loss of their androgen-synthesizing capacity; (f) BMP signalling, in turn, is negatively regulated by GC-derived inhibin and extracellular BMP-binding proteins; (g) diminished BMP signalling could contribute to raised INSL3 and androgen production in conditions such as polycystic ovarian syndrome in humans.

in one or more of these local signaling mechanisms at any stage of follicle development. Recognising that most of the experimental evidence thus far has arisen from in vitro studies, the challenge remains to define which are the most important local signaling mechanisms in terms of physiological regulation in the whole animal context.

\section{Acknowledgements}

The authors acknowledge the financial support of the Biotechnology and Biological Sciences Research Council, UK.

\section{References}

Abel MH, Wootton AN, Wilkins V, Huhtaniemi I, Knight PG \& Charlton HM 2000 The effect of a null mutation in the follicle-stimulating hormone receptor gene on mouse reproduction. Endocrinology 141 1795-1803.

Anand-Ivell R, Tremellen K, Dai Y, Heng K, Yoshida M, Knight PG, Hale GE \& Ivell R 2013 Circulating insulin-like factor 3 (INSL3) in healthy and infertile women. Human Reproduction 28 3093-3102.

Baird DT \& McNeilly AS 1981 Gonadotrophic control of follicular development and function during the oestrous cycle of the ewe. Journal of Reproduction and Fertility Supplement 30 119-133.

Baptiste CG, Battista MC, Trottier A \& Baillargeon JP 2010 Insulin and hyperandrogenism in women with polycystic ovary syndrome. Journal of Steroid Biochemistry and Molecular Biology 122 42-52.

Barbieri RL, Makris A, Randall RW, Daniels G, Kistner RW \& Ryan KJ 1986 Insulin stimulates androgen accumulation in incubations of ovarian stroma obtained from women with hyperandrogenism. Journal of Clinical 
Endocrinology and Metabolism 62 904-910.

Berisha B \& Schams D 2005 Ovarian function in ruminants. Domestic Animal Endocrinology 29 305-317.

Brankin V, Quinn RL, Webb R \& Hunter MG 2005 Evidence for a functional bone morphogenetic protein (BMP) system in the porcine ovary. Domestic Animal Endocrinology 28 367-379.

Buratini J, Jr., Pinto MG, Castilho AC, Amorim RL, Giometti IC, Portela VM, Nicola ES \& Price CA 2007 Expression and function of fibroblast growth factor 10 and its receptor, fibroblast growth factor receptor $2 \mathrm{~B}$, in bovine follicles. Biology of Reproduction 77 743-750.

Campbell BK, Mann GE, McNeilly AS \& Baird DT 1990 The pattern of ovarian inhibin, estradiol, and androstenedione secretion during the estrous cycle of the ewe. Endocrinology 127 227-235.

Campbell BK, Gordon BM \& Scaramuzzi RJ 1994 The effect of ovarian arterial infusion of transforming growth factor alpha on ovarian follicle populations and ovarian hormone secretion in ewes with an autotransplanted ovary. Journal of Endocrinology 143 13-24.

Campbell BK, Baird DT \& Webb R 1998 Effects of dose of $\mathrm{LH}$ on androgen production and luteinization of ovine theca cells cultured in a serum-free system. Journal of Reproduction and Fertility 112 69-77.

Campbell BK, Souza CJ, Skinner AJ, Webb R \& Baird DT 2006 Enhanced response of granulosa and theca cells from sheep carriers of the FecB mutation in vitro to gonadotropins and bone morphogenic protein-2, -4 , and -6. Endocrinology 147 1608-1620.

Campbell BK, Clinton M \& Webb R 2012 The role of antiMullerian hormone $(\mathrm{AMH})$ during follicle development in a monovulatory species (sheep). Endocrinology 153 4533-4543.

Deanesly R 1938 The Androgenic Activity of Ovarian Grafts in Castrated Male Rats. Proceedings of the Royal Society of London Series B Biological Sciences 126 122-135.

Elvin JA, Clark AT, Wang P, Wolfman NM \& Matzuk MM 1999 Paracrine actions of growth differentiation factor-9 in the mammalian ovary. Molecular Endocrinology 13 1035-1048.

Erickson GF, Magoffin DA, Dyer CA \& Hofeditz C 1985 The ovarian androgen producing cells: a review of structure/ function relationships. Endocrine Reviews 6 371-399.

Fortune JE \& Armstrong DT 1977 Androgen production by theca and granulosa isolated from proestrous rat follicles. Endocrinology 100 1341-1347.

Franks S, Gilling-Smith C, Watson H \& Willis D 1999 Insulin action in the normal and polycystic ovary. Endocrinology and Metabolism Clinics of North America 28 361-378.

Fraser HM 2006 Regulation of the ovarian follicular vasculature. Reproductive Biology and Endocrinology 418.

Fraser HM \& Duncan WC 2009 SRB Reproduction, Fertility and Development Award Lecture 2008. Regulation and manipulation of angiogenesis in the ovary and endometrium. Reproduction, Fertility, and Development 21 377-392.

Gambineri A, Patton L, Prontera O, Fanelli F, Ciampaglia W, Cognigni GE, Pagotto U \& Pasquali R 2011 Basal insulin-like factor 3 levels predict functional ovarian hyperandrogenism in the polycystic ovary syndrome. Journal of Endocrinological Investigation 34 685-691.

Gilling-Smith C, Willis DS \& Franks S 1997 Oestradiol feedback stimulation of androgen biosynthesis by human theca cells. Human Reproduction 12 1621-1628.

Glister C, Tannetta DS, Groome NP \& Knight PG 2001 Interactions between follicle-stimulating hormone and growth factors in modulating secretion of steroids and inhibin-related peptides by nonluteinized bovine granulosa cells. Biology of Reproduction 65 1020-1028.

Glister C, Kemp CF \& Knight PG 2004 Bone morphogenetic protein (BMP) ligands and receptors in bovine ovarian follicle cells: actions of BMP-4, -6 and -7 on granulosa cells and differential modulation of Smad-1 phosphorylation by follistatin. Reproduction 127 239-254.

Glister C, Richards SL \& Knight PG 2005 Bone morphogenetic proteins (BMP) $-4,-6$, and -7 potently suppress basal and luteinizing hormone-induced androgen production by bovine theca interna cells in primary culture: could ovarian hyperandrogenic dysfunction be caused by a defect in thecal BMP signaling? Endocrinology 146 1883-1892.

Glister C, Satchell L \& Knight PG 2010 Changes in expression of bone morphogenetic proteins (BMPs), their receptors and inhibin co-receptor betaglycan during bovine antral follicle development: inhibin can antagonize the suppressive effect of BMPs on thecal androgen production. Reproduction 140 699-712.

Glister C, Satchell L \& Knight PG 2011 Granulosal and thecal expression of bone morphogenetic protein- and activinbinding protein mRNA transcripts during bovine follicle development and factors modulating their expression in vitro. Reproduction 142 581-591.

Glister C, Satchell L, Bathgate RA, Wade JD, Dai Y, Ivell R, Anand-Ivell R, Rodgers RJ \& Knight PG 2013 Functional link between bone morphogenetic proteins and insulinlike peptide 3 signaling in modulating ovarian androgen production. Proceedings of the National Academy of Sciences of the USA 110 E1426-1435.

Gutierrez CG, Campbell BK \& Webb R 1997 Development of a long-term bovine granulosa cell culture system: induction and maintenance of estradiol production, response to follicle-stimulating hormone, and morphological characteristics. Biology of Reproduction 56 608-616.

Harlow CR, Hillier SG \& Hodges JK 1986 Androgen modulation of follicle-stimulating hormone-induced granulosa cell steroidogenesis in the primate ovary. Endocrinology 119 1403-1405.

Hillier SG \& De Zwart FA 1981 Evidence that granulosa cell aromatase induction/activation by follicle-stimulating hormone is an androgen receptor-regulated process invitro. Endocrinology 109 1303-1305.

Hoang YD, McTavish KJ, Chang RJ \& Shimasaki S 2013 Paracrine regulation of theca androgen production by granulosa cells in the ovary. Fertility and Sterility $\mathbf{1 0 0}$ 561-567.

Honda A, Hirose M, Hara K, Matoba S, Inoue K, Miki H, Hiura H, Kanatsu-Shinohara M, Kanai Y, Kono T, 
Shinohara T \& Ogura A 2007 Isolation, characterization, and in vitro and in vivo differentiation of putative thecal stem cells. Proceedings of the National Academy of Sciences of the USA 104 12389-12394.

Hunter RF 2003 Physiology of the Graafian Follicle and Ovulation. Cambridge: Cambridge University Press.

Hurwitz A, Hernandez ER, Resnick CE, Packman JN, Payne DW \& Adashi EY 1990 Basic fibroblast growth factor inhibits gonadotropin-supported ovarian androgen biosynthesis: mechanism(s) and site(s) of action. Endocrinology 126 3089-3095.

Hurwitz A, Payne DW, Packman JN, Andreani CL, Resnick CE, Hernandez ER \& Adashi EY 1991 Cytokinemediated regulation of ovarian function: interleukin-1 inhibits gonadotropin-induced androgen biosynthesis. Endocrinology 129 1250-1256.

Itami S, Yasuda K, Yoshida Y, Matsui C, Hashiura S, Sakai A \& Tamotsu S 2011 Co-culturing of follicles with interstitial cells in collagen gel reproduce follicular development accompanied with theca cell layer formation. Reproductive Biology and Endocrinology 9159.

Ivell R \& Anand-Ivell R 2011 Biological role and clinical significance of insulin-like peptide 3. Current Opinion in Endocrinology Diabetes and Obesity 18 210-216.

Joyce IM, Pendola FL, Wigglesworth K \& Eppig JJ 1999 Oocyte regulation of kit ligand expression in mouse ovarian follicles. Developmental Biology 214 342-353.

Knight PG \& Glister C 2006 TGF-beta superfamily members and ovarian follicle development. Reproduction 132 191-206.

Kumar TR, Wang Y, Lu N \& Matzuk MM 1997 Follicle stimulating hormone is required for ovarian follicle maturation but not male fertility. Nature Genetics 15 201-204.

Lagaly DV, Aad PY, Grado-Ahuir JA, Hulsey LB \& Spicer LJ 2008 Role of adiponectin in regulating ovarian theca and granulosa cell function. Molecular and Cellular Endocrinology 284 38-45.

Luo W \& Wiltbank MC 2006 Distinct regulation by steroids of messenger RNAs for FSHR and CYP19A1 in bovine granulosa cells. Biology of Reproduction 75 217-225.

Luo W, Gumen A, Haughian JM \& Wiltbank MC 2011 The role of luteinizing hormone in regulating gene expression during selection of a dominant follicle in cattle. Biology of Reproduction 84 369-378.

Lussier JG, Matton P, Guilbault LA, Grasso F, Mapletoft RJ \& Carruthers TD 1994 Ovarian follicular development and endocrine responses in follicular-fluid-treated and hemi-ovariectomized heifers. Journal of Reproduction and Fertility 102 95-105.

Magoffin DA 2002 The ovarian androgen-producing cells: a 2001 perspective. Reviews of Endocrine and Metabolic Disorders 3 47-53.

Magoffin DA 2005 Ovarian theca cell. International Journal of Biochemistry and Cell Biology 37 1344-1349.

Magoffin DA \& Weitsman SR 1994 Insulin-like growth factor-I regulation of luteinizing hormone (LH) receptor messenger ribonucleic acid expression and $\mathrm{LH}$-stimulated signal transduction in rat ovarian theca-interstitial cells. Biology of Reproduction 51 766-775.
Martin GB 1984 Factors affecting the secretion of luteinizing hormone in the ewe. Biological Reviews 59 1-87.

Miyamoto A, Shirasuna K, Shimizu T, Bollwein H \& Schams D 2010 Regulation of corpus luteum development and maintenance: specific roles of angiogenesis and action of prostaglandin F2alpha. Society for Reproduction and Fertility Supplement 67 289-304.

Monget P, Fabre S, Mulsant P, Lecerf F, Elsen JM, Mazerbourg S, Pisselet C \& Monniaux D 2002 Regulation of ovarian folliculogenesis by IGF and BMP system in domestic animals. Domestic Animal Endocrinology 23 139-154.

Nilsson EE \& Skinner MK 2002 Growth and differentiation factor-9 stimulates progression of early primary but not primordial rat ovarian follicle development. Biology of Reproduction 67 1018-1024.

Nilsson E, Parrott JA \& Skinner MK 2001 Basic fibroblast growth factor induces primordial follicle development and initiates folliculogenesis. Mloecular and Cellular Endocrinology 175 123-130.

Orisaka M, Mizutani T, Tajima K, Orisaka S, Shukunami K, Miyamoto K \& Kotsuji F 2006a Effects of ovarian theca cells on granulosa cell differentiation during gonadotropin-independent follicular growth in cattle. Molecular Reproduction and Development 73 737744.

Orisaka M, Tajima K, Mizutani T, Miyamoto K, Tsang BK, Fukuda S, Yoshida Y \& Kotsuji F 2006b Granulosa cells promote differentiation of cortical stromal cells into theca cells in the bovine ovary. Biology of Reproduction 75 734-740.

Orisaka M, Jiang JY, Orisaka S, Kotsuji F \& Tsang BK 2009 Growth differentiation factor 9 promotes rat preantral follicle growth by up-regulating follicular androgen biosynthesis. Endocrinology 150 2740-2748.

Otsuka F \& Shimasaki S 2002 A negative feedback system between oocyte bone morphogenetic protein 15 and granulosa cell kit ligand: its role in regulating granulosa cell mitosis. Proceedings of the National Academy of Sciences of the USA 99 8060-8065.

Ouellette Y, Price CA \& Carriere PD 2005 Follicular fluid concentration of transforming growth factor-beta1 is negatively correlated with estradiol and follicle size at the early stage of development of the first-wave cohort of bovine ovarian follicles. Domestic Animal Endocrinology 29 623-633.

Parrott JA \& Skinner MK 1997 Direct actions of kit-ligand on theca cell growth and differentiation during follicle development. Endocrinology 138 3819-3827.

Parrott JA \& Skinner MK 1998 Thecal cell-granulosa cell interactions involve a positive feedback loop among keratinocyte growth factor, hepatocyte growth factor, and Kit ligand during ovarian follicular development. Endocrinology 139 2240-2245.

Parrott JA \& Skinner MK 2000 Kit ligand actions on ovarian stromal cells: effects on theca cell recruitment and steroid production. Molecular Reproduction and Development 55 55-64.

Parrott JA, Vigne JL, Chu BZ \& Skinner MK 1994 Mesenchymal-epithelial interactions in the ovarian 
follicle involve keratinocyte and hepatocyte growth factor production by thecal cells and their action on granulosa cells. Endocrinology 135 569-575.

Portela VM, Machado M, Buratini J, Jr., Zamberlam G, Amorim RL, Goncalves P \& Price CA 2010 Expression and function of fibroblast growth factor 18 in the ovarian follicle in cattle. Biology of Reproduction $\mathbf{8 3}$ 339-346.

Ren Y, Cowan RG, Harman RM \& Quirk SM 2009 Dominant activation of the hedgehog signaling pathway in the ovary alters theca development and prevents ovulation. Molecular Endocrinology 23 711-723.

Roberts AJ \& Skinner MK 1990 Mesenchymal-epithelial cell interactions in the ovary: estrogen-induced theca cell steroidogenesis. Molecular and Cellular Endocrinology 72 R1-5.

Roberts AJ \& Skinner MK 1991 Transforming growth factor-alpha and -beta differentially regulate growth and steroidogenesis of bovine thecal cells during antral follicle development. Endocrinology 129 2041-2048.

Robinson RS, Woad KJ, Hammond AJ, Laird M, Hunter MG \& Mann GE 2009 Angiogenesis and vascular function in the ovary. Reproduction 138 869-881.

Rodgers RJ \& Irving-Rodgers HF 2010 Morphological classification of bovine ovarian follicles. Reproduction 139 309-318.

Ryan KJ \& Petro Z 1966 Steroid biosynthesis by human ovarian granulosa and thecal cells. Journal of Clinical Endocrinology and Metabolism 26 46-52.

Satchell L, Glister C, Bleach EC, Glencross RG, Bicknell AB, Dai Y, Anand-Ivell R, Ivell R \& Knight PG 2013 Ovarian expression of insulin-like peptide 3 (INSL3) and its receptor (RXFP2) during development of bovine antral follicles and corpora lutea and measurement of circulating INSL3 levels during synchronized estrous cycles. Endocrinology 154 1897-1906.

Scaramuzzi RJ \& Downing JA 1995 The in vivo effects of fibroblast growth factor and epidermal growth factor on the secretion of oestradiol, androstenedione and progesterone by the autotransplanted ovary in the ewe. Journal of Endocrinology 146 301-311.

Schreiber NB, Totty ML \& Spicer LJ 2012 Expression and effect of fibroblast growth factor 9 in bovine theca cells. Journal of Endocrinology 215 167-175.

Shiina H, Matsumoto T, Sato T, Igarashi K, Miyamoto J, Takemasa S, Sakari M, Takada I, Nakamura T, Metzger D, Chambon P, Kanno J, Yoshikawa H \& Kato S 2006 Premature ovarian failure in androgen receptordeficient mice. Proceedings of the National Academy of Sciences of the USA 103 224-229.

Shimasaki S, Moore RK, Otsuka F \& Erickson GF 2004 The bone morphogenetic protein system in mammalian reproduction. Endocrine Reviews 25 72-101.

Shimizu T, Magata F, Abe Y \& Miyamoto A 2012 Bone morphogenetic protein 4 (BMP-4) and BMP-7 induce vascular endothelial growth factor expression in bovine granulosa cells. Animal Science Journal 83 663-667.

Simpson ER 2003 Sources of estrogen and their importance. Journal of Steroid Biochemistry and Molecular Biology 86 225-230.
Solovyeva EV, Hayashi M, Margi K, Barkats C, Klein C, Amsterdam A, Hsueh AJ \& Tsafriri A 2000 Growth differentiation factor-9 stimulates rat theca-interstitial cell androgen biosynthesis. Biology of Reproduction 63 1214-1218.

Spicer LJ 1998 Tumor necrosis factor-alpha (TNF-alpha) inhibits steroidogenesis of bovine ovarian granulosa and thecal cells in vitro. Involvement of TNF-alpha receptors. Endocrine 8 109-115.

Spicer LJ 2001 Leptin: a possible metabolic signal affecting reproduction. Domestic Animal Endocrinology 21 251-270.

Spicer LJ \& Echternkamp SE 1995 The ovarian insulin and insulin-like growth factor system with an emphasis on domestic animals. Domestic Animal Endocrinology 12 223-245.

Spicer LJ, Voge JL \& Allen DT 2004 Insulin-like growth factor-II stimulates steroidogenesis in cultured bovine thecal cells. Molecular and Cellular Endocrinology 227 1-7.

Spicer LJ, Aad PY, Allen DT, Mazerbourg S, Payne AH \& Hsueh AJ 2008 Growth differentiation factor 9 (GDF9) stimulates proliferation and inhibits steroidogenesis by bovine theca cells: influence of follicle size on responses to GDF9. Biology of Reproduction $\mathbf{7 8}$ 243-253.

Spicer LJ, Sudo S, Aad PY, Wang LS, Chun SY, Ben-Shlomo I, Klein C \& Hsueh AJ 2009 The hedgehog-patched signaling pathway and function in the mammalian ovary: a novel role for hedgehog proteins in stimulating proliferation and steroidogenesis of theca cells. Reproduction 138 329-339.

Tajima K, Orisaka M, Mori T \& Kotsuji F 2007 Ovarian theca cells in follicular function. Reproduction and Biomedicine Online 15 591-609.

Velazquez MA, Spicer LJ \& Wathes DC 2008 The role of endocrine insulin-like growth factor-I (IGF-I) in female bovine reproduction. Domestic Animal Endocrinology 35 325-342.

Vendola K, Zhou J, Wang J, Famuyiwa OA, Bievre M \& Bondy CA 1999 Androgens promote oocyte insulin-like growth factor I expression and initiation of follicle development in the primate ovary. Biology of Reproduction 61 353-357.

Voss AK \& Fortune JE 1993 Levels of messenger ribonucleic acid for cytochrome P450 17 alphahydroxylase and P450 aromatase in preovulatory bovine follicles decrease after the luteinizing hormone surge. Endocrinology 132 2239-2245.

Weil S, Vendola K, Zhou J \& Bondy CA 1999 Androgen and follicle-stimulating hormone interactions in primate ovarian follicle development. Journal of Clinical Endocrinology and Metabolism 84 2951-2956.

Wijgerde M, Ooms M, Hoogerbrugge JW \& Grootegoed JA 2005 Hedgehog signaling in mouse ovary: Indian hedgehog and desert hedgehog from granulosa cells induce target gene expression in developing theca cells. Endocrinology 146 3558-3566.

Woodruff TK \& Mather JP 1995 Inhibin, activin and the female reproductive axis. Annual Reviews of Physiology 57 219-244. 
Wrathall JH \& Knight PG 1995 Effects of inhibin-related peptides and oestradiol on androstenedione and progesterone secretion by bovine theca cells in vitro. Journal of Endocrinology 145 491-500.

Xue K, Kim JY, Liu JY \& Tsang BK 2014 Insulin-like 3-Induced Rat Preantral Follicular Growth Is Mediated by Growth Differentiation Factor 9. Endocrinology 155 156-167.

Yamamoto N, Christenson LK, McAllister JM \& Strauss JF, 3rd 2002 Growth differentiation factor-9 inhibits 3'5'-adenosine monophosphate-stimulated steroidogenesis in human granulosa and theca cells. Journal of Clinical Endocrinology and Metabolism $\mathbf{8 7}$ 2849-2856.

Yang MY \& Fortune JE 2006 Testosterone stimulates the primary to secondary follicle transition in bovine follicles in vitro. Biology of Reproduction 75 924-932.

Yang MY \& Fortune JE 2007 Vascular endothelial growth factor stimulates the primary to secondary follicle transition in bovine follicles in vitro. Molecular Reproduction and Development 74 1095-1104.

Young JM \& McNeilly AS 2010 Theca: the forgotten cell of the ovarian follicle. Reproduction 140 489-504.

Young JM \& McNeilly AS 2012 Inhibin removes the inhibitory effects of activin on steroid enzyme expression and androgen production by normal ovarian thecal cells. Journal of Molecular Endocrinology $\mathbf{4 8}$ 49-60.

Young JM, Henderson S, Souza C, Ludlow H, Groome N \& McNeilly AS 2012 Activin B is produced early in antral follicular development and suppresses thecal androgen production. Reproduction 143 637-650.

Zheng X, Price CA, Tremblay Y, Lussier JG \& Carriere PD 2008 Role of transforming growth factor-beta1 in gene expression and activity of estradiol and progesteronegenerating enzymes in $\mathrm{FSH}$-stimulated bovine granulosa cells. Reproduction 136 447-457. 